\title{
Monetary and Exchange Rate Policy of the Central Bank of the Republic of Turkey
}

Validova A.F.

\author{
Kazan Federal University, Institute of Management, Economics and Finance, Kazan, 420008, Russia
}

Email: avalidova@gmail.com

\author{
Doi:10.5901/mjss.2014.v5n28p74
}

\section{Abstract}

This paper evaluates the monetary and exchange rate policy of the Republic of Turkey in the period of financial liberalization, and defines the role of the Central bank in implementation of the monetary policy and maintaining price stability. We trace the development of central banking in Turkey and its interaction with government, and show the trend towards increasing the independence of Central bank of Turkey with primary responsibility for price stability. The paper also analyses the outcomes of financial liberalization and the main reasons of the financial crises.

Keywords: monetary policy, central bank, exchange rate, financial crisis, inflation

\section{Introduction}

The primary goal of the monetary policy is to maintain the price and real exchange rates stability as well as sustainable long term economic growth. Efforts of monetary authorities have been always directed towards achieving the stated goal but the ways and instruments for attaining the financial stability used in different times and different countries had been varied from one another. In different periods of the economic history Turkish policy makers also applied for various models of economic development and different orientations of monetary policy.

Central Bank is the entity that implements the monetary policy of the country. Generally Central banks are responsible for issuing banknotes, regulating the money supply, managing the country's gold and foreign exchange reserves, determination of the reserve requirements, the function of the government's banker and the bankers' bank. The foundation of the Central bank institution is an important stage of the evolution of the county's banking system. The process of creation of the Central bank differed in various countries: in most of them it followed the centralization of the right to issue banknotes in the hands of the biggest commercial bank which partly assumed the functions of central banking. In some countries, central banks were established by state. However, the advantages of central banking over other alternatives in some amount of time became quite obvious.

The foundation of the central bank of Turkey was preceded by the long period of development of the banking system. Since 1863 the Ottoman Bank to some extent played the role of the central bank and assumed its main functions. Until 1930 the Ottoman bank had the exclusive right and monopoly of issuing banknotes and carried out the Treasure operations. However, the fact that the Ottoman bank was established with foreign capital was against national interests, and soon after the Treaty of Lausanne was signed the Turkish government stated the necessity of establishment of the national central bank to regulate the banking system, manage the monetary policy and protect the value of Turkish currency that lost its stability during World War I period.

For that purpose during the years of the exchange rate crisis with the Law No. 1715 passed on 11 June the Central Bank of the Republic of Turkey (CBTR) was established. It started functioning officially from 3 October, 1931 [13]. According to the law on the CBTR the basic aim of the bank was to support economic development of the country. To fulfill this aim the banks main duties were stated as follows:

- $\quad$ to set rediscount ratios and to regulate money markets;

- to execute Treasury operations;

- to take all measures to protect the value of Turkish currency.

\section{Literature Review}

The history of financial institutions and the practice of central banking has been extensively studied by the scholars of monetary theory and the history of economic thought. Wood (2005) in his work analyses the development of central 
banking " through successive interactions of central bankers, economic ideas, and governments, all affected in greater or lesser degrees by the experiences of earlier developments" [13].

Turkish economist Koklu in his analysis of the Central Bank points at two main duties performed by CBTR according to the law [10]. The first main responsibility of the Bank is regulation of the nations money supply and maintaining the stability of national currency. The other important function is implementation of the credit policy which involves the sphere of credit. By influencing the interest rate Central bank is able to affect money supply and exchange rate.

Koklu emphasises that while the protection of the Turkish currency value was of the crucial importance, very small attention was paid to the credit policy in the first decades of Central Bank's activity. It should be underlined that throughout 1930-50 CBTR did not used some very important monetary policy instruments. Thus, in view of the absence of the developed capital market in Turkey Central bank could not influence the money supply in an economy directly through open market operations. One of the other main characteristics of the Central bank's activity during that period was the lack of independence and too susceptibility to political pressure, the Bank was obliged to finance Treasury in order to cover the budget deficits. In other words, up to 1960s CBTR operated mostly as Government's banker but did not functioned as a banker's bank - its role in the regulation of the banking system was passive.

The link between capital liberalization and financial crises was noted in a variety of empirical works. Kaminsky and Reinhart (1999) showed that in the majority of the cases in their study of the banking crises, the financial systems were previously liberalized, so crises proceeded capital liberalization. Furman and Stiglitz (1998) also argues that financial liberalization was the condition that lead to Asian financial crisis.

\section{Financial Liberalization in the Republic of Turkey}

The significant changes in the monetary sphere of Turkey occurred in 1960-70, when government announced the new economic strategy based on economic development plans. Although this period in the Turkish economic history characterizes by achievements in curbing the inflation, widespread role of the public sector on money markets, dominance of public sector enterprises and state banks eventually led to the economic recession in the late 1970 caused by the structural problems of the Turkish economy. During the period of economic planning in Turkey some very important changes were made in the Central Bank Law. By the new Law No. 1211 accepted on 14 January, 1970 main powers and duties of the CBTR were redefined according to the changes of economic policy and global trends in the central banking law. According to the new Law (with amendments introduced in 1984) monetary policy must be implemented in compliance with the annual development plans, what in fact signified increase of the scope of the government activity. The other major innovation refers to the establishment of such a monetary policy instrument as open market operation. Through buying securities, exchanging money for the security, Central Bank raises the money supply, and conversely by selling securities it lowers the money supply. These changes were followed by further liberalization of the financial system: in the 1980s Central Bank inaugurated interbank money market, foreign exchange market and finally made open market operations to be the main available instrument of the monetary policy.

In the outset of 1980 Turkey experienced a radical structural change and launched the new economic strategy. It was based on expansion of the market mechanism on all the branches of economy and liberalization in the areas of trade and finance. In order to overcome the crisis Turkey chosen the monetarist approach. Among the main measures of the economic liberalization were the reforms in the monetary and banking sector. They included the liberalization of the foreign exchange regime, interbank money market inauguration, interest rate liberalization and introduction of the modern instruments of the monetary policy as discount window and open market operations. In this policy framework Central Banks powers to implement the money and credit policy were considerably enlarged. Turkish government started the restructuring of the banking system to increase efficiency in financial sector and attain its integration with the international money market.

The other serious steps taken by the government concentrated on the liberalization of the capital account which were aimed to introduce the convertibility of the Turkish lira. Finally in 1992 the Turkish lira obtained the status of the convertible currency. It is, therefore, should be underlined that the revaluation of lira and high domestic interest rates on government bonds attracted short-term capital inflows to the country that in its term made the Turkish economy more vulnerable to crises. Some experts argue that the liberalization of capital flows for the post-1989 period has become a major cause of current account instability in Turkish economy.

The other major feature of the Turkish economy was a high and persisting inflation. After several unsuccessful disinflation attempts since 1970s Turkish government with the support of IMF introduced a new anti-inflationary stabilization program which was stated in the "Letters of Intentions" from the December 1999. The primary objective of 
the program was to reduce inflation to single-digit levels and to contribute to the economic growth. The disinflation program was based on the adoption of the crawling-peg regime, that means that the changes in lira value was planned in advance. The exchange rate policy based quasi-currency board limits the increase of the Central bank domestic assets only by foreign exchange reserves. In some extent this program had similarities with Argentinian currency board.

During the first 10 months of its implementation the program was quite successful: inflation slowed down (wholesale price level within the period January-April was 16.5\%), interest rates fell sharply, domestic demand started to increase. Despite of the short period of success during the next six months inflation raised and by the end of the year GNP deflater was $51.5 \%$.

Figure 1. Turkey Inflation Rate.

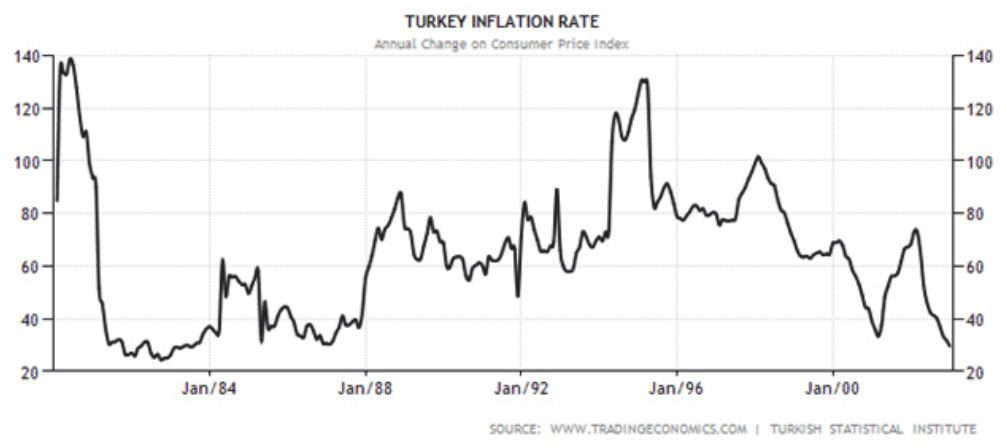

\section{Financial Crisis and Stabilization Program}

The appreciation of the Turkish lira considerably increased the demand for the importing goods and services that caused a higher current account deficit than it was initially planned. As a result of the instability on the Turkish foreign exchange market the capital inflows dropped in the second half of 2000. In other words, economic growth and the increase of inflation in the conditions of non- sterilization rule which was excluded from giving support against the capital flows and cause the contraction of the monetary base finally led to the crisis of the liquidity in December 2000. The liquidity crises was followed by the withdrawal of the foreign financial assets from the Turkish market, and despite of the IMF credit support Central Bank lost most of its foreign reserves, abandoned the crawling-peg regime under the original plan and floated the Turkish lira in February 2001. Figure 2 shows the rapid decline of the foreign exchange reserves and the loss of Turkish lira value against dollar.

Figure 2. Reserves and the exchange rate.

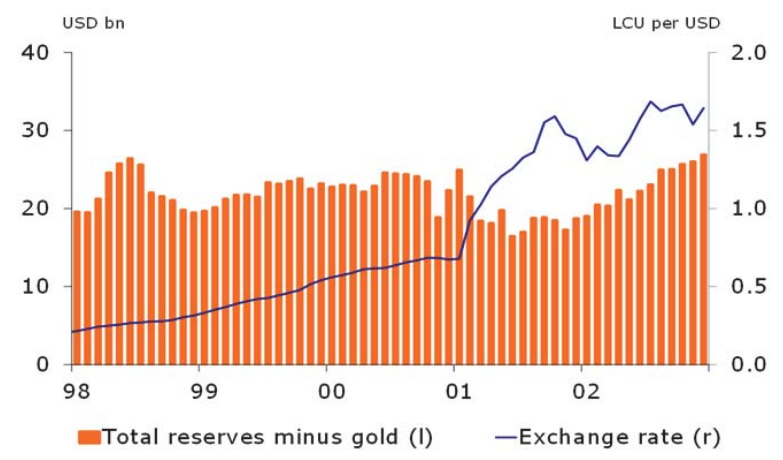

Source: EcoWin

The reasons for and the outcomes of the Turkish-2000 stabilization program were critically analyzed in the large body of the works of well known Turkish and western economists. According to the most studies this crisis was resulted from the huge accumulated domestic debt, fragility of the financial system and weak fundamentals in the Turkish economy. Akcay 
alleges that among the main factors that caused the financial crises were lack of efficient regulation of the banking system, widespread role of the public sector on money markets that made the banking system fragile, corrupted and vulnerable to risks [1].Many western scholars also attribute the ensuing of the crisis conditions to that these crises reflect the the weakness of the national financial sector. Fischer relates the ensuing of crises conditions to banking sector problems and failures to undertake corrective fiscal actions when the current account widened [6].

However, according to Turkish economists the problems of the exchange-rate based anti-inflationary program such as exit strategies were amongst the main reasons of crisis conditions. They argue that IMF stabilization program failed and the crisis deepened in large part because of serious shortcomings in its design and implementation and contribute the major cause of the collapse of the program to the currency board and non- sterilization rule which was excluded from giving support against the capital flows. Yeldan highlights the weaknesses of the exchange rate backed disinflation program as manifested in its liquidity creation mechanism in a small and fragile financial system such as Turkey [5]. In his investigations Onis takes into consideration both internal and external factors that contributed to financial crises. He considers that, on the one hand, these crises were mainly caused by the mistakes of the policy makers in the post capital account liberalization period of Turkish economy, but on the other hand, in a financial globalization environment instability of the international financial markets stemmed by the increase of the fuel prices, appreciation of euro and high interest rates also played their negative role [3].

The consequences of the 2001 crisis to the banking sector and public finances were devastating. Acceleration of the interests rates together with exchange rate uncertainties led to the deterioration of the economic agents confidence and pushed the economy into recession. At the same time in order to overcome the negative impact of the crises a new strengthened economic program has been launched on May 2001.

With the new law passed in April 2001, the primary objective of the Central Bank is stated as to achieve and maintain price stability. According to the new banking law the Central Bank was prohibited to grant advance and extend credit to both Treasury and other public institutions. Consequently, over the past decades CBTR powers and duties evaluated from financing the public sector deficits to the execution of the monetary policy. Withing this framework the trend towards increasing the independence of Central bank of Turkey as a way of improving long-term economic performance should also be underlined. The supervision of the banking system was substantially improved, the amendments made in the Central bank Law broadened its independence. The policies of the monetary authorities since then have been aimed at controlling the volatility of the exchange rate and to prevent excessive fluctuations as a primary goal.

\section{Conclusions}

Among the recent monetary developments we outline the achievement of the policy makers in lowering inflation to single digit levels, decrease of the interest rates and stabilization of the Turkish lira against US dollar and euro. It is of vital importance that a fiscal discipline of the past several years, by reducing the long-term risk premium, has been the key force allowing the achievement output growth during a recent disinflation period. In 2006 Turkish monetary authorities established an inflation targeting framework supported by a free-floating exchange rate system, explicitly announcing annual targets through the Central Bank of the Republic of Turkey.

Consequently, over the past decades CBTR powers and duties evaluated from financing the public sector deficits to the execution of the monetary policy. This important step has been made after success of post-crisis reforms in the financial sector.

The banking sector went through a serious restructuring following the 2001 crisis. However, there are still problems to be solved by the Turkish government in order to achieve more healthy macroeconomic conditions. Slowdown in the global economic activity, high food and energy prices and tight global liquidity conditions have the potential to further restrain disinflation. To sum up, sound monetary and fiscal policies will be the major factors to attain price stability in Turkey. Whether the current monetary arrangements are the best answer to the nowadays challenges can be seen as a topic for current debate.

\section{References}

Akcay O. Cevdet, 2003. The Turkish Banking Sector Two Years after the Crisis: A snapshot of the Sector and Current Risks, The Turkish Economy in Crisis (Editors: Ziya Öniş, Barry Rubin) (Frank Cass: London, Portland, OR., 2003), pp. 169-187.

Akyüz Yilmaz, Boratav Korkut, 2003. The Making of the Turkish Financial Crisis. World Development Vol. 31, No. 9, pp. 1549-1566,

Alper C.Emre, Öniş Ziya, 2002. Emerging Market Crises and the IMF: Rethinking the Role of the IMF in the Light of Turkey's 2000-2001 
Financial Crises, Boğaziçi University Department of Economics Working Papers, ISS/EC-02-03.

Cassis Youssef, 2006. Capitals of Capital: A History of International Financial Centres, 1780- 2005, Cambridge University Press.

Ertuğrul Ahmet, Yeldan Erinç, 2003. On the Structural Weaknesses of the post-1999 Turkish Disinflation Program, The Turkish Economy in Crisis (Editors: Ziya Öniş, Barry Rubin) (Frank Cass: London, Portland, OR, 2003), pp. 54-61.

Fischer S., 2001. Distinguished Lecture on Economics in Government, Journal of Economic Perspectives", Vol.15, No.2, p.11.

Furman, J., Stiglitz, J., 1998. Evidence and insights from East Asia. Brookings Papers on Economic Activity 1-114.

IMF (2002). Turkey: Tenth review under the Stand-By Arrangement. IMF Country Report No. 02/21, February.

Kaminsky, G., Reinhart, C., 1999. The twin crises: the causes of banking and balance-of-payments problems. American Economic Review 89, 473-500.

Köklü Aziz, Türkiede Para Meseleleri "1914-1946 Devresinde Para Siyasetimiz ve Paramizin Kiymeti”. - Ankara, 1947. - Milli Eğitim Basımevi. - Sahifa 42-43.

Özatay, F. and Sak, G., 2002. Banking Sector Fragility and Turkey's 2000-01 Financial Crisis, Brookings Trade Forum 2002: Currency Crises, Washington D.C.

T. C. Merkez Bankası, 1931-1932, Birinci hesapsenesi hakkında İdare Meclisinin, 16 Nisan 1933 - Heyeti Umumiyeye Raporu ve Mürakıplar Raporu, Ankara, 1933.

Wood John H. , 2005. A History of Central Banking in Great Britain and the United States, Cambridge University Press, p. 1.

Ajupov A.A Features of organization of educational process of preparation of economic profile of students based on training dealing center. Procedia - Social and Behavioral Sciences Vol. 131, pp. 97-100 // 3rd World conference on educational technology researches Turkey 07-09.11.2013.

Razumovskaya, E.M. , Kutsevol, N., Popov, M., Mishakin, T., Leto, L., Tsalikova, V. The effectiveness of management practice in the market of socially important services. Asian Social Science, Volume 10, 28 September 2014, Pages 118-122

Razumovskaya, E.M.,Lapidus, L.V., Mishakin, T.S., Popov, M.L. Features and peculiarities of the Russian passenger rail market development. Mediterranean Journal of Social Sciences vol. 5 (18 SPEC. ISSUE), pp. 165-170. 